\title{
Fatty Acids of Fusobacterium Species: Taxonomic Implications
}

\author{
By ERIK JANTZEN ${ }^{1}$ AND TOR HOFSTAD $2 *$ \\ ${ }^{1}$ National Institute of Public Health, Oslo, Norway \\ ${ }^{2}$ Department of Microbiology, The Gade Institute, University of Bergen, \\ $N$-5000 Bergen, Norway
}

(Received 22 July 1980)

\begin{abstract}
Fatty acids of Fusobacterium species were examined by gas-liquid chromatography. Fusobacterium nucleatum, $F$. necrophorum, $F$. mortiferum, $F$. gonidiaformans and $F$. varium showed similar patterns, characterized by the presence of 3-hydroxytetradecanoate, $n$-tetradecanoate, hexadecenoate, $n$-hexadecanoate, octadecenoate, $n$-octadecanoate and a component having the properties of octadecadienoate. Fusobacterium nucleatum contained 3-hydroxyhexadecanoate as a distinctive character. Simpler fatty acid patterns characterized by the absence of 3-hydroxytetradecanoate and other hydroxy fatty acids were observed in $F$. plauti, the single strain of $F$. prausnitzii and in the majority of strains classified as $F$. russii and $F$. naviforme. Neither methyl-branched nor cyclopropane fatty acids could be detected in any of the strains examined. In addition to fatty acid methyl esters, the chromatographic profiles of all species except $F$. mortiferum, $F$. gonidiaformans and $F$. naviforme contained substantial amounts of fatty aldehyde dimethyl acetals of chain lengths $C_{14}$ to $C_{18}$.
\end{abstract}

\section{INTRODUCTION}

The genus Fusobacterium (Knorr, 1923) includes species of obligately anaerobic, non-spore-forming, motile or non-motile Gram-negative rods. Their habitat is the mucous membranes of man and animals (Moore \& Holdeman, 1974). Most species do not normally cause infection in healthy humans, but some, especially $F$. nucleatum and $F$. necrophorum, are not infrequently isolated from clinical material (Sutter et al., 1974). Thus, interest in differentiating species of Fusobacterium has increased, and there have been considerable improvements in the nomenclature and classification of the genus (Holdeman et al., 1977). However, the number of stable and specific tests available for differentiation is still limited. Additional taxonomic characters are required for a more precise definition of the genus as well as for a more accurate description of the species of the genus.

Gas-liquid chromatography (g.l.c.) of metabolic end-products plays an important role in the classification of anaerobic bacteria including Fusobacterium (Holdeman et al., 1977). G.l.c. of cellular fatty acids has proved very useful in differentiating facultative as well as obligately anaerobic bacteria (Lambert \& Armfield, 1979; Lechevalier, 1977; Shaw, 1974) but has only been applied to a limited extent in the study of Fusobacterium (Miyagawa et al., 1979).

The present paper deals with the fatty acid composition of nine species of Fusobacterium. The aim was to establish new and stable chemotaxonomic characters that would be useful in the classification and identification of these anaerobic organisms.

\section{METHODS}

Strains and cultivation. The 31 test strains examined are listed in Table 1. The strains of $F$. plauti were originally isolated from cultures of Entamoeba histolytica (Moore \& Holdeman, 1974). The majority of the other 


\section{Table 1. Fusobacterium strains studied}

\begin{tabular}{|c|c|c|}
\hline Species & Strain designation & Source* \\
\hline $\begin{array}{l}\text { F. nucleatum } \\
\text { F. nucleatum } \\
\text { F. nucleatum } \\
\text { F. nucleatum } \\
\text { F. nucleatum }\end{array}$ & $\begin{array}{l}\text { Fev I } \\
\text { F1 } \\
\text { F8 } \\
\text { F15 } \\
\text { ATCC } 10953\end{array}$ & $\begin{array}{c}1 \\
\text { Own isolate } \\
\text { Own isolate } \\
\text { Own isolate } \\
2\end{array}$ \\
\hline $\begin{array}{l}\text { F. necrophorum } \\
\text { F. necrophorum } \\
\text { F. necrophorum }\end{array}$ & $\begin{array}{l}\text { SPH } 1 \\
\text { VPI } 6161 \\
\text { N167 }\end{array}$ & $\begin{array}{l}3 \\
4 \\
5\end{array}$ \\
\hline $\begin{array}{l}\text { F. mortiferum } \\
F . \text { mortiferum } \\
\text { F. mortiferum } \\
\text { F. mortiferum }\end{array}$ & $\begin{array}{l}\text { VPI } 4249 \\
\text { VPI } 5696=\text { Finegold B } 609 \\
\text { VPI } 0473 \\
\text { VPI } 4123 \mathrm{~A}=\text { ATCC } 25557=\text { Prévot } 350 \mathrm{~A}\end{array}$ & $\begin{array}{l}4 \\
4 \\
4 \\
4\end{array}$ \\
\hline $\begin{array}{l}F . \text { gonidiaformans } \\
F . \text { gonidiaformans } \\
\text { F. gonidiaformans } \\
F \text {.gonidiaformans }\end{array}$ & $\begin{array}{l}\text { VPI } 4381=\text { Prévot } 470 \mathrm{D} \\
\text { VPI } 0482 \mathrm{~A}=\text { ATCC } 25563=\text { Prévot } 3554 \mathrm{~A} \\
\text { VPI } 4879 \\
\text { VPI } 11360\end{array}$ & $\begin{array}{l}4 \\
4 \\
4 \\
4\end{array}$ \\
\hline $\begin{array}{l}\text { F. varium } \\
\text { F.varium } \\
\text { F.varium } \\
\text { F.varium }\end{array}$ & $\begin{array}{l}\text { VPI } 4234=\text { Prévot } 587 \mathrm{~A} \\
\text { VPI } 0499 \mathrm{~A}=\text { Prévot } 1669 \mathrm{BA} \\
\text { ATCC } 8501 \\
\text { Lille } 109\end{array}$ & $\begin{array}{l}4 \\
4 \\
6 \\
6\end{array}$ \\
\hline $\begin{array}{l}F . \text { naviforme } \\
F . \text { naviforme } \\
F . \text { naviforme }\end{array}$ & $\begin{array}{l}\text { VPI } 4877=\text { Prévot } 1800 \\
\text { VPI } 11936 \mathrm{C} \\
\text { VPI } 12188\end{array}$ & $\begin{array}{l}4 \\
4 \\
4\end{array}$ \\
\hline $\begin{array}{l}\text { F. russii } \\
\text { F. russii } \\
\text { F. russii }\end{array}$ & $\begin{array}{l}\text { VPI } 0307=\text { ATCC } 25533=\text { Prévot } 593 \mathrm{~A} \\
\text { VPI } 10646 \\
\text { VPI } 11018\end{array}$ & $\begin{array}{l}4 \\
4 \\
4\end{array}$ \\
\hline $\begin{array}{l}\text { F. plauti } \\
\text { F. plauti } \\
\text { F. plauti } \\
\text { F.plauti }\end{array}$ & $\begin{array}{l}\text { VPI } 0310=\text { Prévot S } 1 \\
\text { VPI } 0311=\text { Prévot S } 2 \\
\text { VPI } 0312=\text { Prévot S } 4 \\
\text { VPI } 4145=\text { Prévot S } 3\end{array}$ & $\begin{array}{l}4 \\
4 \\
4 \\
4\end{array}$ \\
\hline F.prausnitzii & VPI 4815 & 4 \\
\hline
\end{tabular}

* 1, S. E. Mergenhagen, NIDR, Bethesda, Md., U.S.A. 2, American Type Culture Collection, Rockville, Md., U.S.A. 3, T. Justesen, Copenhagen, Denmark. 4, L. V. Holdeman, Virginia Polytechnic Institute and State University, Blacksburg, Va., U.S.A. 5, E. Barnes, Food Research Institute, Norwich, England. 6, E. Beerens, Faculte de Pharmacie, Lille, France.

strains are human isolates. Strains were cultivated on Brucella blood agar plates ( $7 \%$ human blood) at $37{ }^{\circ} \mathrm{C}$ for $48 \mathrm{~h}$ in a deoxygenated $\mathrm{CO}_{2}$ atmosphere (BBL GasPak jars). Bacterial growth was then washed from the agar using a right-angled glass rod and sterile distilled water. Biomass was sedimented by centrifugation at $3000 \mathrm{~g}$ for $20 \mathrm{~min}$, washed twice with distilled water, freeze-dried and stored under nitrogen in closed vials at $-20^{\circ} \mathrm{C}$.

Chemicals. Solvents of analytical grade were distilled before use. The $2 \mathrm{M}-\mathrm{HCl}$ in methanol was obtained by bubbling dry $\mathrm{HCl}$ gas (Fluka, Buchs, Switzerland) into dried methanol until saturation and subsequent dilution. Fatty acid methyl ester standards, including linoleate (cis,cis-9,12-octadecadienoate) and linolelaidate (trans,trans9,12-octadecadienoate), were obtained from Applied Science Laboratories (State College, Pa., U.S.A.) and fatty aldehyde dimethyl acetal standards from Supelco (Bellefonte, Pa., U.S.A.).

Methanolysis and extraction. Freeze-dried bacteria ( 1 to $10 \mathrm{mg}$ ) were suspended in $2 \mathrm{M}-\mathrm{HCl}$ in methanol $(3 \mathrm{ml})$ in Teflon-lined screw-capped vials at $85^{\circ} \mathrm{C}$ for $18 \mathrm{~h}$ (Jantzen et al., 1974a, b, 1978). After cooling, the methanolysates were concentrated to about $1.5 \mathrm{ml}$ in a stream of nitrogen and then $3 \mathrm{ml}$ of a $50 \%$ saturated $\mathrm{NaCl}$ solution was added; the mixture was extracted twice with $4.5 \mathrm{ml}$ hexane and the hexane phases were collected using a syringe. The hexane was evaporated to near dryness using dry nitrogen at room temperature, and the volume was adjusted with hexane to $100 \mu \mathrm{l}$. The samples were stored in sealed glass tubes at $-20^{\circ} \mathrm{C}$.

Separation of methyl esters and methyl acetals. Where substantial amounts of dimethyl acetals were present (see below), these were separated from the fatty acid methyl esters by the procedure of Meyer \& Meyer (1971). After methanolysis and extraction as described above, the methyl esters were saponified in $0.5 \mathrm{M}-\mathrm{NaOH}$ in $90 \%$ methanol $(1 \mathrm{ml})$ for $2 \mathrm{~h}$ at $85^{\circ} \mathrm{C}$. This treatment did not affect dimethyl acetals which could then be extracted with hexane $(2 \times 3 \mathrm{ml})$. The remaining fatty acids (converted to sodium salts) were remethylated by adjusting the $\mathrm{pH}$ to 
2 with $6 \mathrm{M}-\mathrm{HCl}$, subsequent treatment with $14 \%(\mathrm{w} / \mathrm{v}) \mathrm{BCl}_{3}$ in methanol (Merck; $\left.0.5 \mathrm{ml}, 100^{\circ} \mathrm{C}, 5 \mathrm{~min}\right)$ and extraction with hexane $(2 \times 3 \mathrm{ml})$.

Thin-layer chromatography (t.l.c.). The presence of hydroxy fatty acids and dimethyl acetals in bacterial methanolysates was examined by t.l.c. Analytical plates $\left(0.2 \mathrm{~mm}\right.$ silica gel $\mathrm{F}_{254}$; Merck) were developed in hexane/diethyl ether $(85: 15, \mathrm{v} / \mathrm{v})$. The spots were visualized either by charring of plates sprayed with $10 \%$ sulphuric acid in ethanol or by an acidified alcoholic solution of 2,4-dinitrophenylhydrazine.

Gas-liquid chromatography. G.l.c. of fatty acid methyl esters and dimethyl acetals was carried out on a Hewlett-Packard 5710 chromatograph equipped with a flame ionization detector. Two standard glass columns $(200 \times 0.2 \mathrm{~cm})$ were used routinely: non-polar - 10\% SE-30 (methyl silicone) on Gas Chrom Q, 100 to 120 mesh; polar - 10\% Silar-10C (cyanopropyl silicone) on Gas Chrom Q, 100 to 120 mesh (Applied Science Laboratories). Additional analyses were performed on a $25 \mathrm{~m}$ WCOT SE-30 glass capillary column (Chrompack, Middelburg. The Netherlands). The two standard columns were operated from 120 to $250{ }^{\circ} \mathrm{C}$ increasing at $2{ }^{\circ} \mathrm{C} \mathrm{min}-1$ with a carrier gas (nitrogen) flow rate of $20 \mathrm{ml} \mathrm{min}^{-1}$, injection port temperature of $250^{\circ} \mathrm{C}$ and flame ionization detector temperature of $300^{\circ} \mathrm{C}$. The glass capillary column was operated in splitless mode using a Hewlett-Packard $18740 \mathrm{~B}$ capillary column control and with a carrier gas (helium) flow rate of $1.5 \mathrm{ml} \mathrm{min}^{-1}$; the column oven temperature was programmed from 170 to $250^{\circ} \mathrm{C}$ at a rate of $4{ }^{\circ} \mathrm{C} \mathrm{min}-1$.

Peak areas were recorded by a Hewlett-Packard 3380A digital integrator as a percentage of the total peak area. These values were then adjusted by the response factor of each fatty acid (K. Bryn \& E. Jantzen, unpublished results). The responses of underivatized hydroxy fatty acids were generally poor and variable in our chromatographic system. These constituents were therefore quantified after trifluoroacetylation (see below), 'on column' injection and chromatography on the standard SE-30 column.

Identification of fatty acids. Fatty acid methyl esters were primarily identified by comparing their retention times on both the non-polar and polar columns with those of the standards. The identities of hydroxy fatty acids were confirmed by determination of their retention times before and after conversion to trifluoroacetyl derivatives (Jantzen et al., 1974a, 1978). The presence of unsaturation and/or cyclopropane substitution in the alkyl chain was examined by the reduction method of Brian \& Gardner (1968). Since methanolic HCl largely degrades cyclopropane fatty acids, a comparison of fatty acid profiles obtained after alkaline and acidic methanolysis, respectively, provides another check for the presence of cyclopropane fatty acids.

Trifluoroacetyl derivatives were formed by heating to boiling for $5 \mathrm{~min}$ with equal volumes of trifluoroacetic anhydride (Merck) and acetonitrile (Merck).

Generally, the fatty acid identities were confirmed by mass spectrometry (m.s.) using a Hewlett-Packard 5992A gas chromatographic/mass spectrometer computer system equipped with a glass capillary column $(25 \mathrm{~m} \times$ $0.5 \mathrm{~mm}$, CP Sil 5, methyl silicone; Chrompack). The quadrupole mass spectrometer was automatically calibrated (AUTOTUNE program) with a perfluorotetrabutylamine reference compound to a fixed set of mass spectral conditions; the intensity ratio of the peaks at $m / e 69,219$ and 502 was adjusted to $100: 35: 2$. The ionization conditions used were $70 \mathrm{eV}$ at $170^{\circ} \mathrm{C}$.

\section{RESULTS}

The fatty acid composition of the 31 test strains is given in Table 2, and four examples of fatty acid profiles are shown in Fig. 1. In all strains the main constituents were straight-chain saturated and monoenoic acids of chain lengths from $\mathrm{C}_{12}$ to $\mathrm{C}_{18}$. In addition, most chromatograms contained peaks which changed position after trifluoroacetylation, thus indicating a compound with a free hydroxyl group in the chain. By g.l.c./m.s. these peaks showed the abundant fragment of $m / e 103$ characteristic of 3-hydroxy fatty acids (Ryhage \& Stenhagen, 1960), and comparison with reference compounds established their identity to 3-hydroxydodecanoate (3-OH-12:0), 3-hydroxytetradecanoate (3-OH-14:0) and 3hydroxyhexadecanoate (3-OH-16:0), respectively.

The monoenoic fatty acids hexadecenoate $(16: 1)$ and octadecenoate $(18: 1)$ were found in all strains examined. In addition, all of the strains contained an additional constituent eluting just in front of $18: 1$ on the methyl silicone column (Fig. 1). This constituent chromatographed together with the 18:2 standard cis,cis-9,12 octadecadienoate (linoleate) on both the polar and non-polar columns. Furthermore, g.l.c. $/ \mathrm{m} . s$. analysis of this peak revealed a molecular ion of $m / e 294$ and a fragmentation pattern identical to that of linoleate. Thus, both the mass spectrum and the g.l.c. retention time data are consistent with the presence of octadecadienoate $(18: 2)$. Neither cyclopropane nor methyl-branched fatty acids, which frequently occur in bacterial lipids, could be detected. 


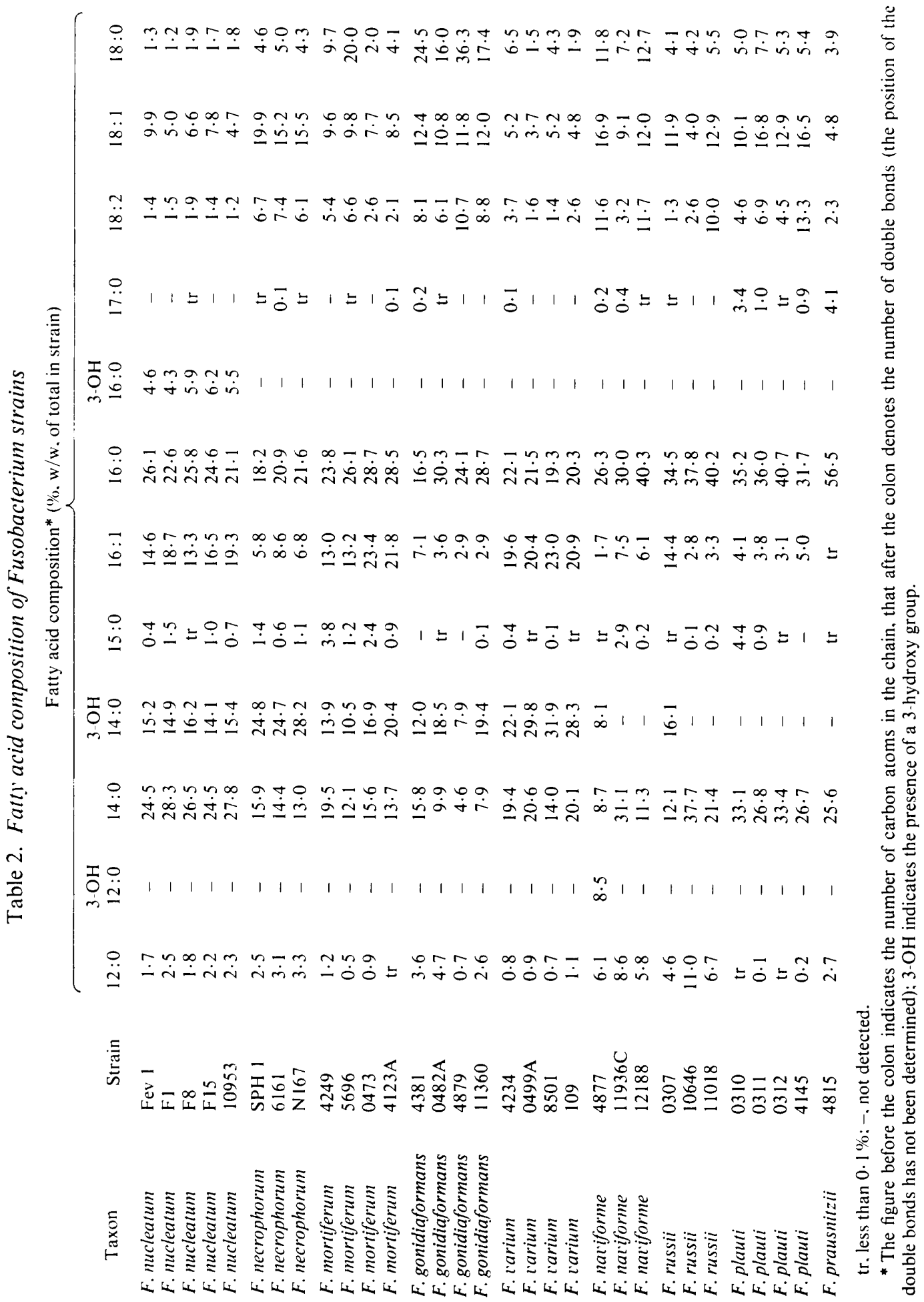



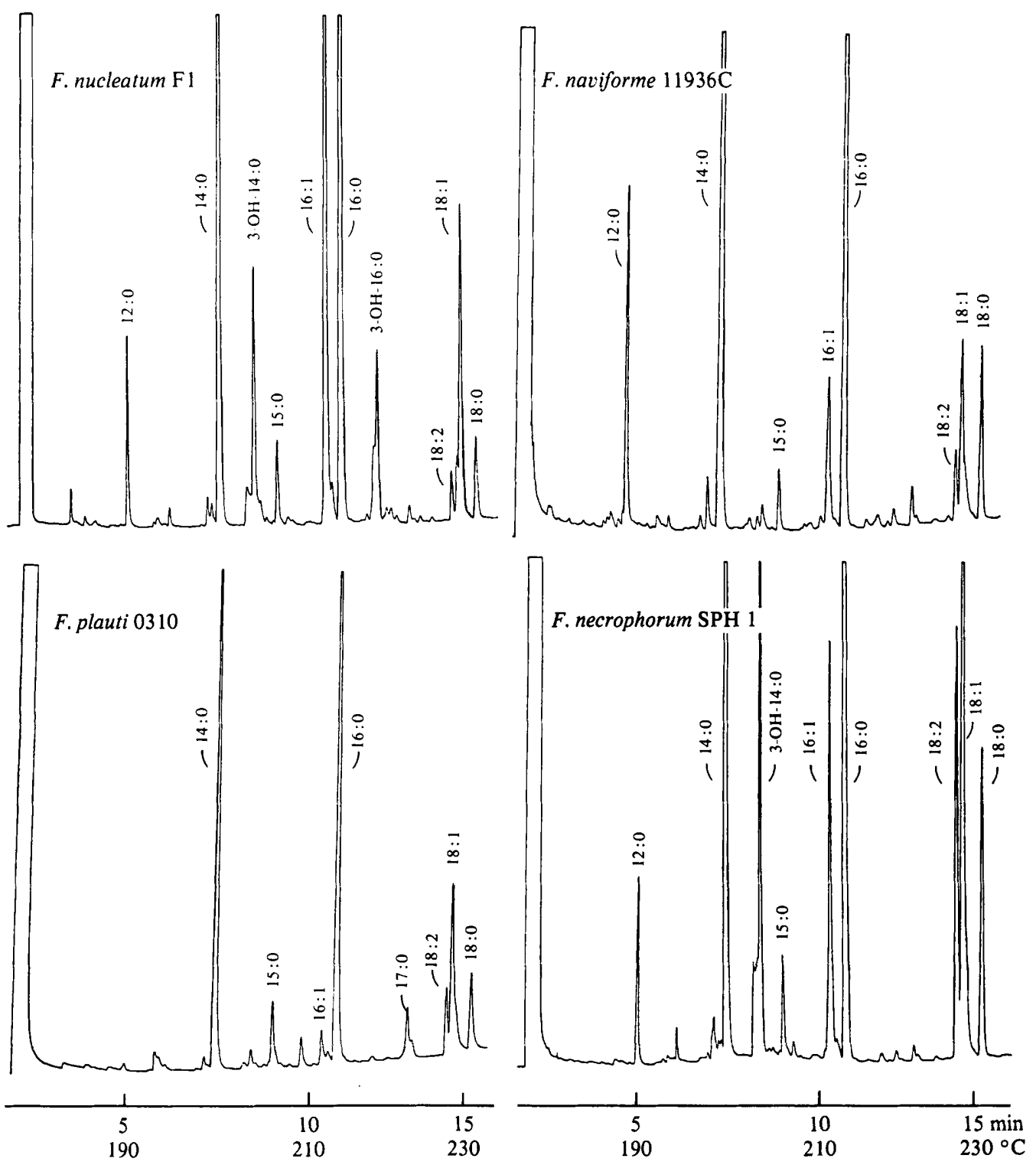

Fig. 1. Typical g.l.c. fatty acid profiles of Fusobacterium strains. Bacteria were digested with $2 \mathrm{M}-\mathrm{HCl}$ in methanol. Fatty aldehyde dimethyl acetals were removed by saponification and extraction. Hydroxy fatty acids were trifluoroacetylated before injection on the $25 \mathrm{~m} \mathrm{SE}-30$ glass capillary column.

The majority of the Fusobacterium strains showed g.l.c. profiles containing several peaks of non-fatty acid nature. These constituents chromatographed in a non-reproducible manner and changed position or disappeared completely after trifluoroacetylation. This nonreproducible g.l.c. behaviour is compatible with fatty aldehyde dimethyl acetals, well-known reaction products of alk-1'-enyl glycerol ethers (plasmalogens) subjected to methanolysis (Farquhar, 1962; Gray, 1967).

Fatty aldehyde dimethyl acetals are easily separated from fatty acid methyl esters by extraction after first converting the methyl esters to solvent-insoluble sodium salts by a mild saponification procedure. By applying the method of Meyer \& Meyer (1971), fatty acid profiles without interfering substances were obtained (Fig. 1). In most cases, the 
Table 3. Differentiating fatty acid and aldehyde features of the Fusobacterium species examined

\begin{tabular}{|c|c|c|c|}
\hline Species* & $\begin{array}{l}\text { Non-hydroxy-fatty } \\
\text { acid characteristics }{ }^{\dagger}\end{array}$ & $\begin{array}{l}\text { Hydroxy-fatty } \\
\text { acids present }\end{array}$ & $\begin{array}{l}\text { Chain length of } \\
\text { the fatty aldehydes } \\
\text { present }\end{array}$ \\
\hline F. nucleatum (5) & $\begin{array}{l}18: 0(1 \cdot 2-1.9 \%) \\
18: 2(1 \cdot 2-1.9 \%)\end{array}$ & $\begin{array}{l}3-\mathrm{OH}-14: 0 \\
3-\mathrm{OH}-16: 0\end{array}$ & $C_{16: 0}$ \\
\hline F. necrophorum (3) & $\begin{array}{l}16: 1(5 \cdot 8-8 \cdot 6 \%) \\
18: 1(15 \cdot 2-19 \cdot 9 \%)\end{array}$ & $3-\mathrm{OH}-14: 0$ & $\begin{array}{l}\mathrm{C}_{14: 0}, \mathrm{C}_{16: 1}, \mathrm{C}_{16: 0} \\
\mathrm{C}_{18: 0}\end{array}$ \\
\hline F. mortiferum (4) & $\begin{array}{l}12: 0(\operatorname{tr}-1 \cdot 2 \%), \\
15: 0(0 \cdot 9-3 \cdot 8 \%)\end{array}$ & $3-\mathrm{OH}-14: 0$ & ND \\
\hline F. gonidiaformans (4) & $\begin{array}{l}16: 1(2 \cdot 9-7 \cdot 1 \%) \\
18: 0(16 \cdot 0-36 \cdot 3 \%)\end{array}$ & 3-OH-14:0 & ND \\
\hline F.varium (4) & $\begin{array}{l}16: 1(19 \cdot 6-23 \cdot 0 \%) \\
18: 1(3 \cdot 7-5 \cdot 2 \%)\end{array}$ & 3-OH-14:0 & $C_{14: 0}, C_{16: 1}, C_{16: 0}$ \\
\hline F. naviforme $4877 \ddagger$ & $16: 1(1 \cdot 7 \%)$ & $\begin{array}{l}3-\mathrm{OH}-12: 0 \\
3-\mathrm{OH}-14: 0\end{array}$ & ND \\
\hline (2) & $\begin{array}{l}12: 0(5 \cdot 8-8 \cdot 6 \%) \\
16: 0(30 \cdot 0-40 \cdot 3 \%)\end{array}$ & ND & ND \\
\hline F. russii $0307 \ddagger$ & $16: 0(34.5 \%)$ & $3-\mathrm{OH}-14: 0$ & ND \\
\hline (2) & $\begin{array}{l}12: 0(6 \cdot 7-11 \cdot 0 \%) \\
14: 0(21.4-37.7 \%)\end{array}$ & ND & $C_{16: 0}, C_{18: 0}$ \\
\hline F.plauti (4) & $\begin{array}{l}12: 0(\operatorname{tr}-0 \cdot 2 \%) \\
14: 0(26 \cdot 7-33 \cdot 4 \%) \\
16: 0(31 \cdot 7-40 \cdot 7 \%)\end{array}$ & ND & $C_{14: 0}, C_{16: 0}$ \\
\hline F.prausnitzii (1) & $\begin{array}{l}16: 0(56 \cdot 5 \%) \\
17: 0(4 \cdot 1 \%)\end{array}$ & ND & ND \\
\hline
\end{tabular}

ND, Not detected.

* Numbers in parentheses indicate the number of strains examined: see Table 1 for descriptions.

† Fatty acids are designated as in Table 2. Numbers in parentheses indicate the range among the strains (data from Table 2).

$\ddagger$ Deviating strain.

corresponding g.l.c. and g.l.c./m.s. profiles of the non-fatty acid material showed a few abundant and several minor peaks. The main peaks in a majority of chromatograms showed identical retention times to those of the $n$-tetradecanal dimethyl acetal (14:0 DMA) and/or $n$-hexadecanal dimethyl acetal (16:0 DMA) standards. In addition, some chromatograms showed peaks whose retention times indicated the presence of hexadecenal dimethyl acetal (16:1 DMA) and/or $n$-octadecanal dimethyl acetal (18:0 DMA) (Table 3). Several of the less abundant peaks were probably decomposition products which were formed in the injection port of the gas chromatograph (Mahadevan et al., 1967).

Mass spectrometry of the non-fatty acid constituents provided further structural evidence. Thus, the mass spectra of the main g.l.c. peaks were all characterized by the diagnostic fragments $\left.\mathrm{CH}\left(\mathrm{OCH}_{3}\right)_{2}^{+}(m / e) 75\right),\left(\mathrm{M}-\mathrm{CH}_{3} \mathrm{OH}\right)^{+}$and, in some cases, $\mathrm{M}^{+}(\mathrm{McFadden}$ et al., 1964). Most of the minor g.l.c. peaks yielded an abundant fragment of $m / e 71$ which may be $\left(\mathrm{CH}_{2} \mathrm{CH}=\mathrm{CHOCH}_{3}\right)^{+}$, a fragment one would expect to be formed from methyl vinyl ethers, which are reported to be a heat-induced degradation product of fatty aldehyde dimethyl acetals (Mahadevan et al., 1967).

The presence of fatty acid dimethyl acetals was also confirmed by t.l.c. analysis. In these experiments methanolysates of selected strains were applied to analytical thin-layer plates. In addition to the spots of hydroxylated fatty acid methyl esters and unsubstituted fatty acid 
methyl esters, several strains (Table 3) showed a distinct spot of $R_{F}$ value and colour corresponding to that of the dimethyl acetal standard (14:0 DMA + 16:0 DMA).

Strains classified as $F$. nucleatum, $F$. necrophorum, $F$. mortiferum, $F$. gonidiaformans and $F$. varium contained the common lipopolysaccharide constituent 3-OH-14:0. Within this cluster of hydroxy fatty acid-containing species, the $F$. nucleatum strains formed a homogeneous sub-group with $3-\mathrm{OH}-16: 0$ as a distinct character (Fig. 1, Table 2). The remaining species had a grossly similar fatty acid pattern and could only be distinguished on the basis of minor quantitative differences. Thus, the three species of $F$. necrophorum contained relatively small amounts of $16: 1$ and large amounts of $18: 1$ compared with the others within this group, whereas $F$. gonidiaformans could be distinguished by its high content of $18: 0$, and $F$. varium by high contents of $3-\mathrm{OH}-14: 0$ and $16: 1$. The fatty acid pattern of $F$. mortiferum was less distinct, although the content of 15:0 appeared to be somewhat higher and that of 12:0 somewhat lower than for other species within this group. The hydroxy fatty acid-containing strains of $F$. russii (VPI 0307) and of $F$. naviforme (VPI 4877), the only strain containing 3-OH-12:0, were both easily distinguishable from the other strains with these constituents (Table 2).

All four strains of $F$. plauti, the strain of $F$. prausnitzii, $F$. russii strains VPI 10646 and VPI 11018 , and $F$. naviforme strains VPI $11936 \mathrm{C}$ and VPI 12188 formed another cluster. This cluster showed a fatty acid pattern characterized by the absence of hydroxy acids and the presence of major amounts of $14: 0$ and $16: 0$.

\section{DISCUSSION}

On the basis of their fatty acid patterns, representatives of the Fusobacterium species examined fell into two distinct groups. One group was characterized by the presence of 3-OH-14:0 and contained all of the strains of $F$. nucleatum, $F$. necrophorum, $F$. gonidiaformans, $F$. mortiferum and $F$. varium together with $F$. russii VPI 0307 and $F$. naviforme VPI 4877. The second group, characterized by the absence of 3-OH-14:0, comprised all strains of $F$. plauti, the single strain of $F$. prausnitzii and the remaining strains of $F$. russii and $F$. naviforme. Within both groups several interspecific and intraspecific differences (Table 3 ) were detected.

Hydroxylated fatty acids are most frequently reported to occur in Gram-negative bacteria (Lechevalier, 1977) where they are constituents of endotoxic lipopolysaccharides (LPS) (Lüderitz et al., 1974). Hase et al. (1977) showed that 3-OH-14:0 and 3-OH-16:0 were present as an integral part of LPS isolated from three strains of $F$. nucleatum. This finding has recently been confirmed by a study of nine additional strains of this species (Hofstad \& Skaug, 1980). The same authors found that LPS preparations from $F$. necrophorum, $F$. mortiferum, $F$. gonidiaformans and $F$. varium contained 3-OH-14:0 as the only hydroxylated fatty acid. Accordingly, the hydroxy fatty acids detected in whole cells of Fusobacterium species are, at least in part, of LPS origin. The presence of 3-OH-16:0 solely in $F$. nucleatum strains suggests that this compound may be a useful taxonomic marker of this species.

Hydroxylated fatty acids have also been found in ornithine lipids of different bacteria (Thiele \& Schwinn, 1974) and in sphingolipids of the genus Bacteroides (Miyagawa et al., 1978; White et al., 1969). The sphingolipids of Bacteroides species contain small amounts of 3-OH-16:0 in addition to 3-hydroxy-15-methylhexadecanoic acid, which is the main hydroxylated fatty acid. However, organisms belonging to this genus are easily distinguished from Fusobacterium species by their content of methyl-branched non-hydroxylated fatty acids (Fritsche, 1974; Miyagawa et al., 1979).

The absence of hydroxy fatty acids in F. plauti, F. prausnitzii, F. russii (VPI 10646 and VPI 11018) and $F$. naviforme (VPI 11936C and VPI 12188) suggests that these strains may have cell walls with atypical LPS composition, or no LPS. Support for this suggestion is 
provided by the failure to isolate LPS from these strains by phenol/water extraction (Hofstad \& Skaug, 1980). These findings imply that $F$. plauti and the other organisms lacking hydroxylated fatty acids may constitute a cluster which is phylogenetically distant to the other fusobacteria.

All strains examined contained a component having the properties of octadecadienoate (18:2). With a few exceptions (Fulco, 1970: Uchida, 1975) most bacteria apparently lack the biosynthetic apparatus for making di-unsaturated acids (Goldfine, 1972). Whether the octadecadienoate of the Fusobacterium species examined is a result of cellular uptake from the medium or a biosynthetic product was not determined. Thus, the taxonomic significance of the quantitative differences among the strains with respect to this compound is presently not known.

Fatty aldehyde dimethyl acetals were found in substantial amounts in many, but not in all, of the organisms studied (Table 3). Such lipid constituents are well-known reaction products formed by methanolysis of alk-1'-enyl glyceryl ethers (plasmalogens). Ether lipids of this kind occur in a number of anaerobic organisms (Hagen \& Goldfine, 1967; Kamio et al., 1969) including Fusobacterium (Sphaerophorus ridiculosus) (Hagen, 1974) but not in aerobic bacteria (Lechevalier, 1977). At present the influence of environmental factors on the biosynthesis of plasmalogens is not known. The taxonomic value of this group of lipids or their aldehyde constituents is therefore uncertain.

Two main taxonomic implications of the results of the present study are evident. Firstly, the spindle-shaped organism $F$. nucleatum contains 3-OH-16:0 and is therefore distinct, on the basis of fatty acid content, from the pleomorphic organisms $F$. necrophorum, $F$. mortiferum, F. gonidiaformans and F. varium, species classified as Sphaerophorus by Prévot (1938) and Prévot \& Fredette (1966). Secondly, the marked difference in fatty acid composition between the hydroxy fatty acid-containing species and $F$. plauti, the strain of $F$. prausnitzii and the non-hydroxy fatty acid-containing strains of $F$. naviforme and $F$. russii may indicate that the latter are representatives of a group of non-spore-forming organisms phylogenetically distant to both Fusobacterium and Bacteroides. It is of relevance in this connection that $F$. prausnitzii with a G + C content of DNA of 50 to $57 \mathrm{~mol} \%$ (Cato et al., 1974) can be readily distinguished from the hydroxy fatty acid-containing species of Fusobacterium examined, which fall into the range 26 to $34 \mathrm{~mol} \%$ (Moore \& Holdeman, 1974; Page \& Krywolap, 1976).

As presently defined, the only stable character differentiating Fusobacterium species from other anaerobic Gram-negative non-spore-forming rods is the production of butyric acid as a major product from the fermentation of glucose or peptone. The results of the present study suggest that other criteria, including lipid constituents, should be included in the generic description of Fusobacterium.

We are most grateful to those who have supplied us with strains, in particular to Dr W. E. C. Moore and Dr L. V. Holdeman at the VPI Anaerobe Laboratory. The study was supported in part by the Norwegian Research Council for Science and the Humanities.

\section{REFERENCES}

Brian, B. L. \& Gardner, E. W. (1968). A simple procedure for detecting the presence of cyclopropane fatty acids in bacterial lipids. Applied Microbiology 16, 549-552.

Cato, E. P., Salmon, C. W. \& Moore, W. E. C. (1974). Fusobacterium prausnitzii (Hauduroy et al.) Moore and Holdeman: emended description and designation of neotype strain. International Journal of Systematic Bacteriology 24, 225-229.

FARQUHAR, J. W. (1962). Identification and gas-liquid chromatographic behaviour of plasmalogen al- dehydes and their acetal, alcohol, and acetylated alcohol derivatives. Journal of Lipid Research 3, 21-30.

Fritsche, C. D. (1974). Zur Struktur der Lipoide des Genus Bacteroides. Zentralblatt für Bakteriologie. Parasitenkunde, Infektionskrankheiten und Hygiene (Abteilung I, Originale A) 228, 100-106.

Fulco, A. J. (1970). The biosynthesis of unsaturated fatty acids by bacilli. II. Temperature-dependent biosynthesis of polyunsaturated fatty acids. Journal of Biological Chemistry 245, 2985-2990. 
GoldFINE, H. (1972). Comparative aspects of bacterial lipids. Advances in Microbial Physiology 8, $1-57$.

GRAY, G. M. (1967). Gas chromatography of longchain aldehydes. In Lipid Chromatographic Analysis, vol. 1, pp. 401-427. Edited by G. V. Marinetti. New York: Marcel Dekker.

HAGEN, P.-O. (1974). Lipids of Sphaerophorus ridiculosis: plasmalogen composition. Journal of Bacteriology 119, 643-645.

HaGen, P.-O. \& Goldfine, H. (1967). Phospholipids of Clostridium butyricum. III. Further studies on the origin of the aldehyde chains of plasmalogens. Journal of Biological Chemistry 242, 57005708.

Hase, I., Hofstad, T. \& Rietschel, E. T. (1977) Chemical structure of the lipid A component of lipopolysaccharides from Fusobacterium nucleatum. Journal of Bacteriology 129, 9-14.

Hofstad, T. \& Skaug, N. (1980). Fatty acids and neutral sugars present in lipopolysaccharides isolated from Fusobacterium species. Acta pathologica et microbiologica scandinavica B88, 115-120.

Holdeman, L. V., Cato, E. P. \& Moore, W. E. C. (1977). Anaerobe Laboratory Manual, 4th edn, V.P.I. Anaerobe Laboratory. Blacksburg, Virginia, U.S.A.: Virginia Polytechnic Institute and State University.

JANTZEN, E., Bryn, K. \& Bövre, K. (1974a). Gas chromatography of bacterial whole cell methanolysates. IV. A procedure for fractionation and identification of fatty acids and monosaccharides of cellular structures. Acta pathologica et microbiologica scandinavica B82, 753-766.

Jantzen, E., Bryn, K., Bergan, T. \& Bövre, K. $(1974 b)$. Gas chromatography of bacterial whole cell methanolysates. V. Fatty acid composition of neisseriae and moraxellae. Acta pathologica et microbiologica scandinavica B82, 767-779.

JaNTZEN, E., Bryn, K., HAGEN, N., Bergan, T. \& Bövre, K. (1978). Fatty acids and monosaccharides of Neisseriaceae in relation to established taxonomy. NIPH Annals 1, 59-71.

Kamio, Y., Kanegasaki, S. \& TAKahashi, H. (1969). Occurrence of plasmalogens in anaerobic bacteria. Journal of General and Applied Microbiology 15, 439-451.

KNORR, M. (1923). Über die fusospirilläre Symbiose, die Gattung Fusobacterium (K. B. Lehmann) und Spirillum sputigenum. II. Mitteilung. Die Gattung Fusobacterium. Zentralblatt für Bakteriologie, Parasitenkunde und Infektionskrankheiten (Abteilung I, Originale) 89, 4-22.

LAMbert, M. A. S. \& ARMField, A. Y. (1979). Differentiation of Peptococcus and Peptostreptococcus by gas-liquid chromatography of cellular fatty acids and metabolic products. Journal of Clinical Microbiology 10, 464-476.

LECHEVALIER, H. (1977). Lipids in bacterial taxonomy - a taxonomists view. CRC Critical Reviews in Microbiology 5, 109-210.

Lüderitz, O., Galanos, C., LehmanN, V. \& RIETSCHEL, E. T. (1974). Recent findings on the chemical structure and biological activity of bacterial lipopolysaccharides. Journal of Hygiene,
Epidemiology, Microbiology and Immunology 18, 381-390.

Mahadevan, V., Viswanathan, C. V. \& Phillips, F. (1967). Conversion of fatty aldehyde dimethyl acetals to the corresponding alk-1-enyl methyl ethers (substituted vinyl ethers) during gas-liquid chromatography. Journal of Lipid Research 8, 2-5.

McFadden, W. H., Wasserman, J., Corse, J., Lundin, R. E. \& Teranishi, R. (1964). Correlation and anomalies in mass spectra: acetals. Analytical Chemistry 36, 1031-1037.

MeYER, H. \& MeYeR, F. (1971). Lipid metabolism in the parasitic and free living spirochetes Treponema pallidum (Reiter) and Treponema zuelzerae. Biochimica et biophysica acta 231, 93-106.

Miyagawa, E., Azuma, R. \& Suto, T. (1978). Distribution of sphingolipids in Bacteroides species. Journal of General and Applied Microbiology 24, 341-348.

Miyagawa, E., Azuma, R. \& Suto, T. (1979). Cellular fatty acid composition in gram-negative obligately anaerobic rods. Journal of General and Applied Microbiology 25, 41-51.

Moore, W. E. C. \& Holdeman, L. V. (1974). Genus II. Fusobacterium Knorr 1922, 4. In Bergey's Manual of Determinative Bacteriology, 8th edn, pp. 404-416. Edited by R. E. Buchanan \& N. E. Gibbons. Baltimore: Williams \& Wilkins.

Page, L. R. \& KRYwolap, G. N. (1976). Determination of the deoxyribonucleic acid composition and deoxyribonucleic acid-deoxyribonucleic acid hybridization of Fusobacterium fusiforme, Fusobacterium polymorphum, and Leptotrichia buccalis: taxonomic considerations. International Journal of Systematic Bacteriology 26, 301-304.

PrÉvot, A.-R. (1938). Études de systématique bactérienne. III. Invalidité du genre Bacteroides Castellani et Chalmers. Démembrement et reclassification. Annales de l'Institut Pasteur 60, 285-307.

Prévot, A.-R. \& FredetTE, V. (1966). Manual for the Classification and Determination of the Anaerobic Bacteria. Philadelphia: Lea \& Febiger.

RyHAGE, R. \& STENhagen, E. (1960). Mass spectrometric studies. VI. Methyl esters of normal chain-, oxo-, hydroxy-, methoxy- and epoxyacids. Arkiv för kemi 15, 545-569.

SHAw, N. (1974). Lipid composition as a guide to the classification of bacteria. Advances in Applied Microbiology 17, 63-108.

Sutter, V. L., Attebery, H. R. \& Finegold, S. M. (1974). Gram-negative nonspore forming anaerobic bacilli. In Manual of Clinical Microbiology, 2nd edn, pp. 388-395. Edited by E. H. Lennette, E. H. Spaulding \& J. P. Truant. Washington, D. C.: American Society for Microbiology.

Thiele, O. W. \& SchwinN, G. (1974). Bakterielle Ornithinlipide. Zeitschrift für allgemeine Mikrobiologie 14, 435-443.

UCHIDA, K. (1975). Occurrence of conjugated dienoic fatty acids in the cellular lipids of Pediococcus homari. Agricultural and Biological Chemistry 39, 561-563.

White, D. C., Tucker, A. N. \& Sweeley, C. S. (1969). Characterization of the iso-branched sphinganines from the ceramide phospholipids of Bacteroides melaninogenicus. Biochimica et biophysica acta 187, 527-532. 